\title{
Electrochemical, in-vitro in-vivo study of Co (II)-ofloxacin complex
}

\author{
Deepa Thakur ,Jyotsna Mishra, \\ Department of Chemistry Scope Engineering college,(Bhopal)
}

\begin{abstract}
C o}(\boldsymbol{I I})$ - Ofloxacin complex has been synthesized and screened for its physicochemical, microbial as well as pharmacological activity have been done in solid and aqueous phase. On the basis of elemental analysis, polarographic studies, amperometric titration and IR spectral studies the probable formula for the complex has been determined at $30 \pm 1^{\circ} \mathrm{C}$ and ionic strength of $\mu=1.0[\mathrm{KCl}$. Raper's paper disc method was used for microbial study against various pathogenic bacteria and fungi.Invivo syudy of Swiss mice [25-30gm] were used for antibacterial activity against ofloxacin and its complex on xyline-Alcoholic activity test Kidney, liver and serum of these rats were also studied. On the basis of observed result it could be concluded that Co(II)-Ofloxacin complex were found to be non-toxic and more potent than pure Ofloxacin.(1)
\end{abstract}

Keywords: Fe (III) - Antimicrobial activity, Ofloxacin, in vivo and in vitro ,polarographic and Amperometric study.

\section{Introduction}

The survey of relevant literature reveals that Co (II) have been proven beneficial against several disease such as hair loss, anemia and normal functioning of pancreas (2). The coordination Chemistry of these drugs with metals ions of biological and pharmaceutical (3-6) importance is of considerable interest ofloxacin was considered the best of the third generation quinolone family. Recently we have found the synthesis of a cobalt complex containing the fluoroquinolone ligand, the ofloxine found was characterized by FT-IR, elemental analysis. The crystal structure of this cobalt complex was also characterized and is reported in this paper.

\section{Experimental procedure}

All the chemical were used of analytical grade and which has used without further purification sigma laboratory, USA, Supplied the ofloxine drug. ofloxine $(0.01 \mathrm{M})$ and KCL $(0.1 \mathrm{M})$ have been prepared in conductivity water.

1. Polarograpy All the Polarography measurement have been, recorded on an Elico (India) Pulse Polarograpy model CL- 357 comprising of three electrodes system a

dropping mercury electrode (DME) as working electrode a saturated calomel

electrode (SCE) as reference electrode and a coiled platinum wire as an auxiliary electrode.

Experimental sets were prepared by keeping over all Co (II) potassium chloride supporting electrolyte, concentration fixed at $1.0 \mathrm{mM}$ and $1.0 \mathrm{M}$ respectively. The $\mathrm{pH}$ of the test solution was adjusted to $5.0 \pm 0.2$ as using $\mathrm{NaOH} / \mathrm{HCl}$ solution Hydrogen gas was bubbled through the test solution for about $15 \mathrm{~min}$ before recording the polarogram. The ligand (ofloxacin) concentration was varied from $0.01 \mathrm{mM}$ to $5 \mathrm{mM}$.

2. Amperometric titration of Cobalt (II) -ofloxine complex -

For amperometric titration sets of solution and containing varying concentration of drug were prepared in $0.1 \mathrm{M}$ potassium chloride and titrated against the standard solution of the titled Co (II) ions whose $\mathrm{pH}$ has been adjusted to that of the titrate $(5.0 \pm 0.2)$. The platue potential for Co (II) is $-0.3 \mathrm{~V}$ vs SCE is fixed at potentiometer.

\section{Synthesis of solid complex}

A red colored complex has synthesized by refluxing aqueous solution of Co (II) and ofloxine on 1:1 molar ratio for about $3 \mathrm{~h}$. The complex has marked by precipitation after reducing the volume of reaction mixture to one fourth of the volume the product has filtered, washed, dried over $\mathrm{P}_{4} \mathrm{O}_{10}$ and characterized

\section{IR - spectrometric measurement} was done.

The IR spectrophotometric analysis in solution phase using Perking Elemer-379, IR spectrophotometer 


\section{Antimicrobial Screening}

Raper's method was followed for microbial screening of the complex against various pathogenic bacteria Viz E-Coli, Salmonella typhi (A. aniger \& A. Flavus) number of replicates in each of the case was three. The percentage inhibition was calculated using the formula.

$\%$ inhibition $\frac{a-b}{a} \times 100$

Where $\mathrm{a},=$ diameter of inhibition Zone for complex

$\mathrm{b}=$ diameter of inhibition Zone for metal

\section{Results \& discussion}

In $0.01 \mathrm{M} \mathrm{KCl}$ at $\mathrm{pH} 5.0 \pm 0.2$ ofloxine produced a well-defined polarographic signal in and DCP and DPP model with half-wave potential $\mathrm{E}_{1 / 2}=-1.64 \mathrm{~V}$ vs SCE and peak potential EP=1.40V verse SCE id/ip has found to be proportional to the ofloxine concentration under the above mention conditions, ofloxine is sold under market as antibacterial (100 mg CaPS) medicine, which is soluble in distilled water. Method of standard addition was used to determine the ofloxine content of antibacterial powder, it manufacture "Burrough wellcome", India, thus enabling the quality control of ofloxine in pharmaceutical formulation.

In $0.1 \mathrm{M} \mathrm{KCl}$ at $\mathrm{pH}=5.0 \pm 0.2, \mathrm{Co}$ (II) and its complex with ofloxine produced a well defined reversible and diffusion controlled Polarographic wave which has revealed by the log plot slope and the plots of $i_{d}$ versus $\sqrt{h}$ effective hight of mercury column respectively on the gradual addition of the ligand the $\mathrm{E}_{1 / 2}$ of the metal shifted to more electronegative values indicating the formulation of Co (II) - ofloxine complex Lingane's treatment of the observed polarographic data revealed 1:1 [Co (II)- ofloxine] complex formulation is solution with $\log \beta_{1}=4.48 . V_{h}$

\section{Amperometric titration of Ofloxacin With Co (II) ion}

On gradual addition of Co (II) ion the ofloxine analyzed solution, the current goes on decreasing to minimum and then attends a constant value the plot of $i_{d} \sqrt{h}(V+v / V)$ versus volume of titrant added to the titre, revealed a L-shaped curve the end point has indicate by the intersection of the two line which confirmed 1:1 ML complex formation.(Fig 2)

\section{The IR- Spectra of quinolones}

The analytical data of the ligand and its complexes along with some physical properties are summarized in Table(1). The ligand on interaction with Co (II), Nitrate yield complexes corresponding to the general formula $\left(\mathrm{ML}_{2}\right)$. The low molar conductance value of the complexes reveals their non-electrolytic nature (7). These complex are more soluble in-organic solvents and less soluble in inorganic solvent. Elemental analysis data (Table) show that the metal to ligand ratio is $1: 1$.

In order to study the binding mode of both the ligand to the metal in complexes the IR spectra of the uncompleted ligand were compared with the spectra of metal complexes. The IR spectra of the ligands show a band in the region $1717-1724 \mathrm{~cm}^{-1}$ and $1597-1367 \mathrm{~cm}^{-1}$ assignable to the COOH group (8) the absence of these band in metal complexes.

Reveals the deprotonation of the $\mathrm{COOH}$ group on complexation. These ligands also exhibit their characteristics band in the region 1611-1602 $\mathrm{cm}^{-1}$ assigned azomethine linkage in the ligand. The IR spectra of metal complexes indicate shifting of these band to lower frequencies $\left(1610-1590 \mathrm{~cm}^{-1}\right)$.

Thus confirming the involvement of the azomethine group in bonding with metal ion. The above description of IR data supported the mono anionic bi dentate nature of these investigated ligands. The IR spectra of metal complexes also show new band in the region $470-455 \mathrm{~cm}^{-1}$ and $390-350 \mathrm{~cm}^{-1}$.

\section{Antimicrobial activity*}

The minimal Inhibitory concentration for the bacteria strain listed in table 2 has measured by the agar incorporation method in plastic petri-dish containing muceller Hinton hinton agar $(100 \mathrm{ml})$ and incorporating the antimicrobials in concentration of 0.014 to $63 \mu \mathrm{g} / \mathrm{ML}$ in doubling dilution, following the method of the National centre for drug screening (9-11).

\section{Synthesis of Metal complex with ofloxine}

To a solution of ofloxine $(2 \mathrm{~m} \mathrm{~mol})$ in methanol [ $(10 \mathrm{ml})$, a solution of Metal chloride or sulphate] salt $(2 \mathrm{~m} / \mathrm{mol})$ in methanol $(10 \mathrm{ml})$ was added, the mixture has stirred at heated or refluxed at $60^{\circ} \mathrm{C}$ for $1 \mathrm{hr}$. The resulting solution was filtered. Precipitate formed for Co (II) ofloxine Complex the filtrate has evaporated to one 
third of the initial volume and refrigerator for 2 week this result into formation of crystals; re-crystallization of the crystals has carried out to give suitable crystal for analysis.

Reaction

\section{Antimicrobial Screening}

Mice for experiment have been injected as describe by San chez - Delgado (1969). Swiss mice have divided into 43 -group and 3 in each group, Kept in metal Cage and fed with mice cuber and water alibitum.

$\begin{array}{ll}\text { Group A } & \text { Control } \\ \text { Group B } & \text { ofloxine } \\ \text { Group C } & {\left[\mathrm{Co}(\mathrm{oflo})_{2 .}\left(\mathrm{H}_{2 \mathrm{O}}\right] \cdot 2 \mathrm{H}_{2} \mathrm{O}\right.}\end{array}$

Formula -

$$
\% \text { inhibition }=\frac{100-\text { estimated number parasites treated mice }}{\text { Estimated number of parasites in un treated mice }}
$$

\section{Treatment of animals}

Male albino rats (wistar strain), weighing 160-180g have obtained from the zoology department of chemical science, Ajayi Gowther, university oyo, Nigeria, they have been kept in wire meshed cages and fed with commercial rat chow (Bendal feed Nigeria Ltd.) and supply water alibitum $(12,13)$.

12 rats have divided randomly into 3-group Group A [control] received distill water, Group B have been administer with free ligand [ofloxine], Group C have been administrated with [Co (oflo $)_{2}$. $\left(\mathrm{H}_{20} \mathrm{O}\right] .2 \mathrm{H}_{2} \mathrm{O}$.

The distilled water and solution of ligand and metal complex have been administered orally to the rate in the various group three time daily for 15 day, 30 days 45 days, 60 day at a dose of $3.33 \mathrm{mg} / \mathrm{kg}$ body weight.

\section{Collection of blood sample for Serum Preparation}

The rate have been sacrificed by stunning and cervical dislocation. Blood sample has collected into clean labeled sample bottles. The clear liquid on top has centrifuged at $3000 \mathrm{mg}$ for $10 \mathrm{~min}$ and the supernatant [Serum] has used for the enzyme assay.

\section{Preparation of tissue homogenates}

The method described by yakubu 2005 has used to prepare the tissues. The liver and kidney have been quickly excised from the rats blotted of strain and homogenized in 4 volume of iced cold $0.25 \mathrm{~m}$ sucrose the homogenates have been kept in well- labeled containers and Store in the freezer for further use.

\section{Determination of serum and tissue}

ALP Activities

The serum and tissues ALP activities have been determined using the randox diagnostic kit laboratories manual [1997]. ALP activity determination has based on the method of Wright et. al 1972 modified by akanji 1989(14).

\section{Protein determination}

Protein determination in the serum and the tissue homogenates has estimated by the method of lowry (1951).

Statistical analysis

The data have been analyzed using one way ANOVA, followed by Duncan multivariable 'post hoc' test for comparison between control and treated rats in all group $\mathrm{P}>0.05$ have been considered Statistically significant.

The effects of oral administration of the ligands and the complexes on rat liver, kidney and Serum alkaline phosphate activities are shown in table (4). The serum ALP activities showed slight Significant change $[\mathrm{P}>0.05]$ on comparison with one another and the control after repeated administration of ligand and complexes. The fact that there has no significant difference in serum ALP activities of ligand and ligand-Metal complexes administered rats when compared with control suggested that the integrity of the plasma membrane was not compromised .

Moreover, the observed significant increases in the ALP activities of the liver and kidney of rate administered with ofloxine Complexes suggests and enhancement of the activities of the enzyme by the drugs and their metabolites. The increase may also be as result of stress imposed on the tissue by the drugs, which may lead to loss of the enzyme molecule through leakage into extra cellular fluid which has not been significantly noticed in the serum. In a bid to offset this stress, the tissue may increase the de novo synthesis of the enzyme thus accounting for increase in ALP activities in these tissues (Umezawa and Hooper, 1982) (15).

The research show that the antibacterial activity of ofloxine lignad is more potent as compare to the pure drug. The percentage, of reductions are bacteria $67 \%, 76 \%$, for ofloxine respectively. 


\section{Acknowledgement-}

The authors are thankful to the Head, Department of Electro Chemistry, Dr. Hari Singh Gour University, Sagar for providing necessary laboratory facilities

\section{Reference}

[1]. Davi Puma Sharoda AC, Soloman FE \& Kamath MS, Indian L Exp Biol, 30 (1992) 169.

[2]. Fusk J, Fuskov A, Rosazza J P \& Nicholas A W , Ncaplasma, 31 (1998) 31

[3]. Ghosh MN, Fundamentals of Experimental Pharmacology $2^{\text {nd }}$ (Scientific Book Agency) (1984), 153.

[4]. Devi P Verma, Sharoda AC \& Soloman FF, Indian J Exp biology, 31 (1993) 607.

[5]. Lingane J J, Chem Rev, 1 (1944) 29.

[6]. Organic compound C mentice hall of India Pvt. Ltd. New Delhi (1974) 35.

[7]. Kettle, S, FA, Coordination compound, ALBS \& Nelson, London (1975) 151

[8]. Nakamoto K, Infra red \& Raman spetra of inorganic, \& coordination compound, 3rd Id Willes, int SC Pub, New York, (1977) 2, 313.

[9]. Dormale O, G, Blaimpain, H Agnaniet, T. Nzacliyabi, J.S. Lebibi. L.A. Maciejewsk, C, Biot, A.J, Cateorges \& P. millet, (1998) 42,540

[10]. Hebet R.K. Polborn \& W.C. Bak, (1999), Quwpean Jouired of Jno yank chemistry (1999), 471.

[11]. Fuska I, Fuskov A Rosazza J P \& Nicholas A W , Neoplasma, (1998) 3, 31

[12]. Sanchez delgade, A, R, M, Navarro, J Perez \& J.A. urebina, (1996 ) J medicinal chemistry(1996 ) $39,1095$.

[13]. Orunniran, K.A., A.C. Tella, M. Alensila M.T. Vakubu, J Bio technology( 2007 ) 6, 1202

[14]. Akanji, African J Biochemistry Research, (1993) 3,120.

[15]. Umezawa and Hooper, African J of Biotechnology. (1982) 6(24).

Table 1

IR data of ligand of metal - complexes

\begin{tabular}{|l|l|l|l|l|l|l|l|}
\hline \multirow{2}{*}{ Compound } & \multicolumn{9}{|c|}{ IR $\left(\mathbf{c m}^{-1}\right)$} & V $(\mathrm{M}-\mathrm{N})$ & $\mathrm{V}(\mathrm{M}-\mathrm{O})$ \\
\cline { 2 - 8 } & $\begin{array}{c}\left(\mathrm{COO}^{-}\right) \mathrm{v} \\
(\mathrm{C}-\mathrm{o})\end{array}$ & $\begin{array}{c}\left(\mathrm{COO}^{-}\right) \mathrm{vc}= \\
(\mathrm{C}-\mathrm{o})\end{array}$ & $\mathrm{V}_{\mathrm{a}}\left(\mathrm{COO}^{-}\right)$ & $\mathrm{Vs}\left(\mathrm{COO}^{-}\right)$ & $\mathrm{V}(\mathrm{C}=\mathrm{N})$ & 200 \\
\hline Drug & 1717 & 1597 & - & - & 1626 & 470 & 250 \\
\hline $\begin{array}{l}{\left[\mathrm{Co}(\mathrm{oflo})_{2}\right.} \\
\left(\mathrm{H}_{2 \mathrm{O}}\right] .2 \mathrm{H}_{2} \mathrm{O}\end{array}$ & - & - & 1610 & 1500 & 1609 & 455 & 250 \\
\hline
\end{tabular}

Table - 2

\begin{tabular}{|l|l|l|l|l|}
\hline Compound & \multicolumn{3}{|l|}{} \\
\hline & Staphylococcus A & $\begin{array}{l}\text { Micrococcus, } \\
\text { Lukens }\end{array}$ & E.coli & $\begin{array}{l}\text { Pseudomonas } \\
\text { argue in }\end{array}$ \\
\hline Ciprofloxine & $<20$ & $<20$ & $>20$ & $<20$ \\
\hline $\begin{array}{l}{[\mathrm{Co}} \\
\left(\mathrm{H}_{20}\right] .2 \mathrm{H}_{2} \mathrm{O}\end{array}$ & $<20$ & $>20$ & $<20$ & $>20$ \\
\hline
\end{tabular}

Table - 3

\begin{tabular}{|l|l|l|l|}
\hline \multicolumn{1}{|c|}{ Ligand / complexes } & \multicolumn{1}{|c|}{ Kidney IV / L } & \multicolumn{1}{c|}{ Liver IV / L } & \multicolumn{1}{c|}{ Serum IV / L } \\
\hline Control & $60.16+3.10$ & $20.03+1.80$ & $10.7 \pm 0.95$ \\
\hline ofloxine & $72.30 \pm 5.08$ & $5.13 \pm 3.14$ & $10.00 \pm 0.77$ \\
\hline$\left[\mathrm{Co}(\text { oflo })_{2 .}\left(\mathrm{H}_{2 \mathrm{O}}\right] .2 \mathrm{H}_{2} \mathrm{O}\right.$ & $74.70 \pm 5.10$ & $26.30 \pm 1.06$ & $8.24 \pm 0.64$ \\
\hline
\end{tabular}

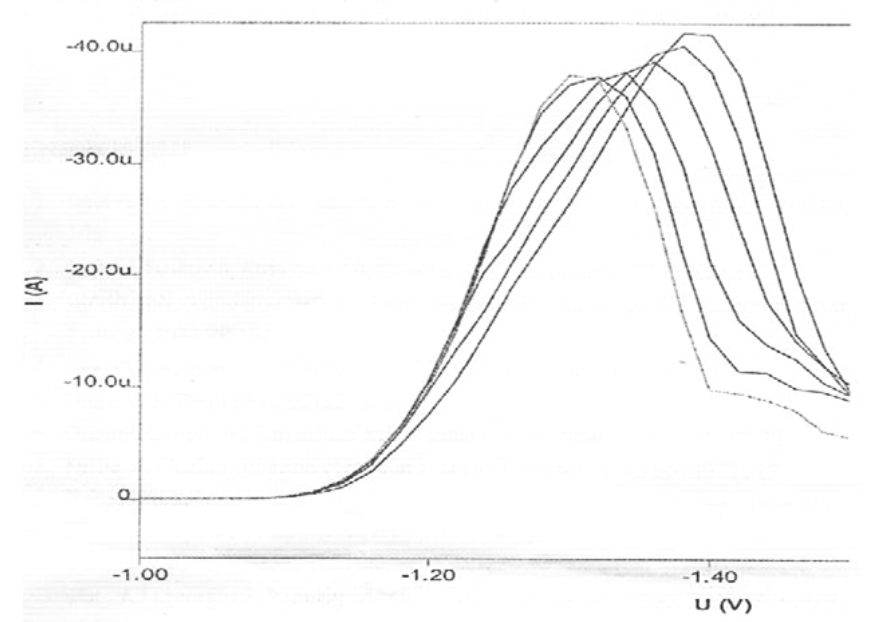

. Fig 1 Polarograms of $\mathrm{Co}(\mathrm{II})(1 \mathrm{mM})$ in $0.1 \mathrm{M} \mathrm{KCl}$ supporting electrolyte at $\mathrm{pH} 5.0 \pm 0.2$ and

1 Without drug

$21 \mathrm{mM}$ drug

$32 \mathrm{mM}$ and $3 \mathrm{mM}$ ofloxacin 


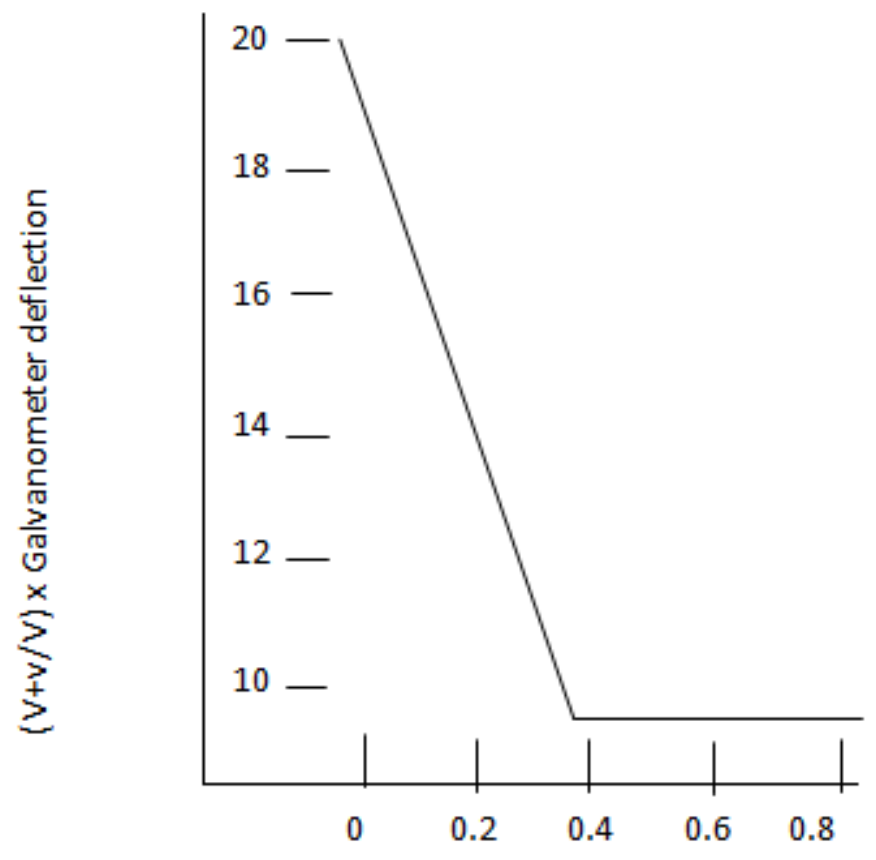

Fig-2 Amperometric titration of $(2 \mathrm{mM} / 10 \mathrm{ml})$ ofloxacin $(1 \mathrm{mM} / 10 \mathrm{ml})$ Co ( II) solution 